received 10 Sep 2014 accepted 17 Oct 2014

One step at a time: international law and the duty to cooperate in the management of shared waters resources

Christina Leb

Water Global Practice, World Bank, Washington, DC, United States

1661 Park Road, NW \#301

Washington, DC 20010

United States

Phone: +1 2026030758

E-mail: Christina.leb@gmx.at 
received 10 Sep 2014 accepted 17 Oct 2014

\title{
One step at a time: international law and the duty to cooperate in the management of shared waters resources
}

\begin{abstract}
Analyzing the dynamics of international cooperation, this article describes the role of international law in the process. It illustrates that international law is a tool to achieve mutually beneficial relations and can be a driver for cooperation. Describing how these dynamics apply to the context of cooperation on transboundary rivers, the article traces the emergence of the general duty to cooperate in international water law as a legal response to the interdependence and coordination requirements in the management and development of shared water resources.
\end{abstract}

Keywords: cooperation; international law; transboundary waters; UN Watercourses Convention; duty to cooperate

\section{Introduction}

Shared water bodies - rivers, lakes and aquifers - create linkages and interdependencies between States. Across the globe, 276 rivers connect the territories of two or more countries (UN Water, 2013a). About 40 percent of the world's population in 148 countries depend on the freshwater resources from these river basins (UN Water, 2013a). Freshwater is becoming an increasingly scarce resource; additionally, population growth and rapid urbanization is putting increasing pressure on global freshwater resources. It is expected that by 2025, 1.8 billion people will live in countries or regions under condition of absolute water scarcity (UN Water, 2013b) partly because water use increases at more than twice the rate of population growth. At the river basin level, the use of the transboundary water system by one State usually impacts on other States sharing the same system through changes in water quality, alteration of river flow or change of water availability over time. Uses can affect another State's physical territory, for example through flow velocity changes that impact the river bed stability and the geomorphology of the 
received 10 Sep 2014 accepted 17 Oct 2014

river, or reduction of flood risk and damage through flow regulation. They can affect existing uses or foreclose future water development opportunities in other parts of the basin, for instance by changing the hydropower potential downstream through upstream development. These impacts may cause harm or they may be beneficial.

In 2013, the International Year of Water Cooperation, several joint declarations from governments, international and regional organizations and civil society were issued that highlight international agreement on the need for cooperative development and management of shared water resources. The Declaration of the High Level International Conference on Water Cooperation, held in Dushanbe in August 2013, recognizes cooperation as essential to ensure "broad-based sustainable economic growth, overall human development, poverty and hunger eradication, public health, food security, energy security, environmental protection, disaster prevention, urban and rural development, resilience to climate change” and stability (INBO, 2013). Similar conclusions were drawn from the World Water Week: Water Cooperation Building Partnerships, held in Stockholm one month later (SIWI, 2013). Furthermore, the Sustainable Development Goals (SGDs), which will define the post-2015 development agenda, recognize the need for cooperation to ensure continued and adequate availability of water for human consumption. Goal 6 of the SDGs, which concerns ensuring the availability and sustainable management of water and sanitation for all, includes as its Target 6.5 that by 2030 integrated water resources management (IWRM) is implemented at all levels, including through transboundary cooperation as appropriate. This article analyzes the dynamics of when States decide that cooperation is appropriate and the tools they use to govern their cooperative relationships. 
received 10 Sep 2014 accepted 17 Oct 2014

\section{International Law as an expression of cooperation between States}

Cooperation is defined as the process by which States take coordination to a level where they work together to achieve a common purpose that produces additional mutual benefits that would not be available to them with unilateral action alone (Zartman, 2008). Thus, when States expect to derive benefits that would otherwise be unachievable, they will seek engagement and collaboration with those States that are in a position to assist them in order to realize additional gains. To shape their process of engagement, States use a variety of tools, including: dialogue at the technical, diplomatic or highest government levels; the exchange of notes, data and information; collaboration between national entities; the establishment of joint institutions; and also international treaties.

\section{Building blocks of cooperation}

People and, later, States that did not own all the resources they needed to fulfill their basic needs or enhance their economic conditions - food supplies, medicinal herbs, wood, coal, metals and ores - engaged in war or trade to gain access. Over the course of history, a complex web of trade relations and rules of peaceful engagement emerged that in addition to resource access created many other benefits through the exchange of knowledge and goods: scientific and technologic advances, higher life expectancy, and increasing resource efficiency to support more and more people. The intention here is not to claim that there were only winners, but to illustrate that cooperative behavior over time generated multiple benefits that may not have been available otherwise. Cooperative behavior to achieve mutual benefits rests on two key building blocks: reciprocity and good faith. To elicit cooperation a first concession must be made; it takes place in good faith that the concession will be reciprocated. When the concession is not reciprocated, 
received 10 Sep 2014 accepted 17 Oct 2014

good faith is frustrated and cooperation and the benefits that can be derived therefrom may never occur.

The interest in sustained mutually beneficial relationships over time leads to consistent behavior of reciprocal concessions and self-restraint to not abuse a relationship for one's own benefit and thus risking to frustrate good faith and cooperation of the other participating parties. Such continued concordant actions establish general rules of behavior. In the international legal system, rules that emerge from widespread State behavior that is consistent over time and accompanied by the belief that it is required by law are considered customary law (ICJ, 1969 and 1986). Thus, law emerges as the result of State cooperation and the interests of States in continued mutually beneficial relationships (Brunnée, 1989). This does not imply that all customary law emerges from relationships between States that seek mutual benefits. Customary rules equally formed based on consistent State behavior that sought to delimit a State's sphere of influence and control. The customary rules on the non-use of force and non-intervention in internal affairs by another State came into being in this manner (ICJ, 1986). In a generous understanding of the concept of benefits, one could argue that these equally represent mutual benefits. The key issue here is that the building blocks of these customary rules and of cooperation are the same: namely, reciprocity and good faith.

The expectation of reciprocity leads States to enter into legal relationships; at the same time they accept restraints to their sovereignty based on the good faith expectation, or trust, that other States will follow suit. In the majority of instances States meet expectations of good faith and reciprocity in their mutual relationships. Throughout history, this has led to increasing economic, political, and legal ties between them. To formalize these relationships States use international treaties as a tool to give these relations more stability and predictability. 
received 10 Sep 2014 accepted 17 Oct 2014

\section{From coexistence to the duty to cooperate in international law}

Overtime, State relations developed from defining rules on their respective spatial, temporal and personal limits and obligations of non-interference to developing rules on mutual assistance and joint action. In addition to these rules of coexistence, a growing body of norms of the so-called law of cooperation emerged alongside them (Sahovič, 1972).

With an increase in economic ties and interdependence between States and their subjects, the law of coexistence proved no longer sufficient to regulate the increasingly multifaceted relations between States. These developments required coordination and joint action. Positive obligations of assistance and action increasingly entered in the body of rules applied by States to their relations (Verdross and Simma, 1984). Increasing commercial relations required cooperation to maintain and access transport and shipping routes. After World War II, concerted international efforts were made to help war-torn economies in their recovery and facilitate their renewed participation in global markets and financial systems with the establishment of two treaty-based organizations, the International Bank for Reconstruction and Development and the International Monetary fund (the Bretton Woods institutions), which later also supported the economic development of countries coming out of colonization. Similarly, the United Nations was established to avoid the destructive consequences of major wars in the future. International cooperation received a new stimulus when the negative environmental effects of human economic activity, including their transboundary impact, became apparent. The recognition that the sustainable management of the natural environment and related issues required cooperation between States and at the universal level led to a significant number of treaties on international cooperation and joint action; most notably those adopted in the context of the 1992 UN Conference on Environment and Development in Rio (UNCED, 1992), including the Convention 
received 10 Sep 2014 accepted 17 Oct 2014

on Biological Diversity (CBD) and the UN Framework Convention on Climate Change (UNFCCC). These Conventions contain rules on the settlement of disputes and established financial mechanisms to assist those countries, which do not have the necessary means, in the compliance with the obligations set out in the Conventions.

In legal terms, these developments continuously broadened the reach of the law of cooperation and the emergence of a general principle of cooperation in international law. The principles and rules included in the Charter of the United Nations (UNC) are commonly considered as one of the key treaty sources from which this general principle can be derived. The UNC reflects the agreement of its now 193 member States on what the latter consider as legally binding rules governing their conduct. In addition to its mandate to maintain international peace and security, the United Nations (UN) have the achievement of "international cooperation in solving international problems of an economic, social, cultural, or humanitarian character, and in promoting and encouraging respect for human rights and for fundamental freedoms for all without distinction as to race, sex, language, or religion" as their objective (Article 1 (3)). The articles of the Charter, in particular Articles 2, 55 and 56 outline specific cooperation duties, including the pledge of States to act jointly and in cooperation with the UN to achieve social and economic development and higher standards of living.

Within the institutional framework of the UN, government representatives reconfirmed their commitment to international cooperation several times, including through UN General Assembly (GA) resolutions, such as the Declaration on Principles of International Law concerning Friendly Relations and Cooperation among States (UNGA, 1970) and the Declaration on the Establishment of a New International Economic Order (UNGA, 1974). These two resolutions, which were adopted at the height of the Cold War and towards the end of the long process of 
received 10 Sep 2014 accepted 17 Oct 2014

decolonization, endorsed the principle of international cooperation among equals for economic development.

\section{Law as tool for incremental cooperation}

The UN system more generally provides examples that illustrate the role of international law in the iterative process of cooperation. The UN was established, based on an international treaty, with a mandate to maintain international peace and security and promote international cooperation (Article 1 UNC). The Charter establishing the UN is in itself an outcome of State cooperation; governments convened for negotiations with the purpose of reaching an agreement that would be mutually beneficial, i.e. averting the harmful impacts of war and to progressively increase the living conditions of their populations.

The structure of the UN Security Council (SC) demonstrates that international treaties are at the same time an outcome of and reflect the political realities at the time of their conclusion. The victorious countries, the Soviet Union (replaced in 1991 by Russia), China, the United Kingdom, the United State and France were granted permanent seats and hold veto power. At the same time, the example of the SC reflects that international treaties can be subject to modification to better reflect changes in underlying circumstance. Recognizing the increase in UN membership, the number of non-permanent SC seats was increased from six to ten, raising the total membership of 15, through an amendment to the Charter which became effective in 1965 (UNGA, 1963). And finally, the continued discussions around permanent membership and SC reform also highlights the general "stickiness" of international treaties that provides stability and at the same time can be the reason that prevents treaties from being adequately adjusted to changing circumstances. 
received 10 Sep 2014 accepted 17 Oct 2014

Another aspect that is common in the process of using law for international cooperation is the agreement by States to relinquish some of their sovereignty by establishing or joining a treatybased institutional framework. The intent of such agreements is most often to curtail one's sovereignty for the benefit of achieving the intended mutual benefits of cooperation more effectively. In the case of the UN, this voluntary self-restriction of sovereignty includes one of its most drastic forms by giving significant decision making power to the SC under Chapter VII of the UNC. Transferring decision making rights to a treaty based mechanisms remains a relatively rare way of restricting sovereignty by for the benefit of cooperation, more common are "softer" forms such as limiting the mandate of joint mechanisms to recommending policy directions.

An additional beneficial role treaty based institutions or joint mechanism play in the cooperation process is the creation of space to incrementally increase the scope and breadth of issue areas of cooperation. States used the UN system to steadily increase the issue areas of cooperation and to deepen cooperation through establishing new rights and obligations. In the field of human rights law for example, the Commission on Human Rights (CHR), a subsidiary body of the UN Economic and Social Council (Chapter X UNC), first drafted the Universal Declaration on Human Rights. In an expression of international political commitment to these rights, the Declaration was adopted by the GA in 1948 in a non-legally binding resolution (UNGA, 1948) and followed up with two treaties, the 1966 International Covenant on Economic, Social and Cultural Rights and the International Covenant on Civil and Political Rights, which outline more detailed rights and obligations of States and individuals. These rights were further defined and the Covenants followed up with a series of other human rights treaties, including those defining in more detail the rights of women and children. To strengthen the institutional framework the Office of the High Commissioner for Human Rights was established in 1993 as a UN agency and 
received 10 Sep 2014 accepted 17 Oct 2014

the CHR was replaced in 2006 by the UN Human Rights Council, a subsidiary body of the General Assembly.

Finally, the UNFCCC framework provides an example how international law can also be used to strengthen the role of or support relatively "weaker" States in the process of international cooperation. It established a principle of common but differentiated responsibilities and mandates more developed countries to take the lead in combating climate change and its harmful effects, including through providing technical and financial assistance to developing countries to meet the costs of adaptation (Articles 3 and 4 UNFCCC).

The above section does not intend to argue that international law is the panacea for the world's challenges, but rather it intends to highlight the many ways in which legal tools can be used to promote cooperation. While willingness of national governments will continue to determine to a large extent the degree of cooperation across borders, international law plays an important role by providing rules that govern the conduct of individual countries (Wouters, 2013a) and give stability and predictability to the relationships among them.

\section{Law and cooperation on international waters}

Similar processes of incremental cooperation (Wouters, 2014) that have deepened and widened the scope of cooperation, and continue to do so, take place in many of the world's transboundary river basins.

\section{Use of law in cooperation on transboundary waters}

States do not always refer to international treaties, but may conduct cooperative engagements through regular meetings or administrative agreements concluded between ministries or 
received 10 Sep 2014 accepted 17 Oct 2014

provinces. In the Brahmaputra Basin, for example, India initiated a joint working group on water and power with Bhutan and Bangladesh, the so-called BIB initiative (CGI, 2014). Furthermore, based on a Memorandum of Understanding (MoU) concluded between the respective Ministries of Water in May 2013, China agreed to provide hydrological data during the flood season to India (FNVA, 2014). One year later the two countries agreed in their implementation plan to this MoU to extend the period during which data will be provided. Such non-treaty-based engagements are typical in particular during early stages of cooperative processes in transboundary basins. In cases where cooperation continues over multiple years or decades, it is common for countries to increasingly formalize their relationships through international treaties to achieve more stability and predictability in their mutual engagements.

In the Rhine River Basin, scientific cooperation to develop a pollution monitoring strategy eventually evolved into a comprehensive legal and institutional framework for river basin management among five riparian countries, including a joint institution, the International Commission for the Protection of the Rhine (ICPR). An international scientific commission was set up in 1950 among five riparian countries by exchange of diplomatic notes to investigate the extent and origin of pollution (Frijters and Leentvaar, 2003). With the expressed intention to strengthen cooperation, the participating countries later decided to provide the Commission with a treaty basis and a clearer mandate on pollution monitoring (Preamble 1963 Agreement on the International Commission for the Protection of the Rhine against Pollution). This 1963 Treaty also included a clause that provided for extending the competence of the Commission to "all other matters which the signatory Governments refer to it by consensus”. In 1999, Germany, France, Luxemburg, Switzerland, and the Netherlands together with the European Union broadened the scope of their cooperation and with it the mandate of their joint institution to 
received 10 Sep 2014 accepted 17 Oct 2014

ecosystem protection, species diversity conservation, flood prevention and flow management among others. Today, the ICPR also ensures coordination with the remaining four riparian countries that are not members of the Commission as well as with the Central Commission for Navigation on the Rhine.

A process of incrementally broadening cooperation equally occurred in the La Plata Basin (LPB). In this case, the widening scope of cooperation occurred also with respect to the geographic scope of cooperation. The process grew from an initially mostly bilateral engagement to study hydropower development on contiguous stretches of key tributaries in the 1940s and 1950s. Technical Commissions were set up between Uruguay and Argentina and Brazil and Paraguay to study the feasibility of exploitation of the power potential at Salto Grande on the Uruguay River, and at Itaipú and Yacyretá on the Paraná River. The three dams were eventually completed in 1979, 1982 and 1994 respectively and are managed by jointly owned mechanisms. In 1967, at a meeting of the foreign ministers of the LPB countries a Coordinating Intergovernmental Committee (CIC) was created to study integrated development of the basin (Biswas, 2013). Based on the work of the CIC, the five LPB countries signed the La Plata Basin Treaty in 1969. The treaty is a framework treaty in which the countries agreed to identify areas of common interest and carry out studies, programs and works on a wider range of issues, including comprehensive basin and water resources management, ecosystem conservation, interconnection of transport systems including by river, integration of power production, and regional cooperation on education and health. The treaty furthermore leaves open the opportunity to adopt additional bilateral or multilateral agreements between the countries for specific projects or deepened cooperation on specific issue areas to achieve the general objectives of "harmonious development and physical integration” of the basin (Articles VI and I LPB Treaty). The CIC, the 
received 10 Sep 2014 accepted 17 Oct 2014

Conference of Foreign Affairs Ministers and the General Secretariat continue to provide an institutional framework for regular dialog and coordination that led, for example, to the adoption of a comprehensive Framework Program for the LPB in 2001 (Pochat, 2011). To finance the cost of joint studies and development, a joint banking mechanism, the Financial Fund for the Development of the LPB (FONPLATA), was established in 1976.

Similar processes of incremental cross-border cooperation that were accompanied by the establishment of institutions and the conclusion of various, sometimes subsequent, legal agreements to establish rules of engagement and actionable rights and obligations among riparian countries occurred in a number of other basins, including the Danube, Nile, Mekong and Senegal River basins (Leb, 2013a). In the case of the Senegal River basin, decade-long cooperation reached the unique level at which basin countries agreed to co-own infrastructure assets that are located not on contiguous river stretches, but exclusively on the territory of individual riparian countries.

\section{Emergence of cooperation duty in international water law}

As described in an earlier article published in this journal (Leb, 2013b), the engagement of States in cooperative management and development of transboundary river basins and their use of international treaties to formalize their relationships has led to the emergence of the general duty to cooperate as a principle of international water law. Similar to the development in international law, there was a trend away from rules determining coexistence towards establishing principles and norms of cooperation (Boisson de Chazournes, 2005). The majority of early water related treaties focused on the drawing of political boundaries along rivers or across lakes, allocating 
received 10 Sep 2014 accepted 17 Oct 2014

exclusive fishing rights, and regulating transit rights and river navigation for ships flying the flag of one State across the territory of another State.

A significant step towards rules on cooperation and joint action occurred first mostly with the increased trend of harnessing the hydropower potential of transboundary rivers and later when impacts of economic activity on riverine ecosystems negatively impacted human water uses. Given that rivers were used as landmarks to draw international boundaries, a number of important hydropower sites are located on contiguous river stretches, requiring cross-border infrastructure development for the exploitation of their potential. The treaty regime established in the La Plata river basin described above, as well as agreements on other joint projects, such as the 1963 Agreement relating to the Iron Gates Water Power and Navigation System and the1977 Treaty concerning the Gabčíkovo-Nagymaros System of Locks, both on the Danube River, are well known examples.

Heavy industrialization along rivers and their usage as natural sewage drains, eventually led to a new set of water treaties focusing on integrated basin management and furthering rules of cooperation. Cumulative effects of water pollution and river regulation works for navigation and power development significantly impacted availability of safe water supplies for drinking and other domestic uses, reduced or led to localized extinction of fish stock and increased the flood risks along transboundary rivers. Comprehensive basin management treaties, such as the 1994 Danube Protection Convention and the 1999 Convention on the Protection of the Rhine with their strong focus on water quality restoration and ecosystem protection, were a response to the transboundary impacts of economic activity along rivers. Based on the second Convention, the ministers in charge of water resources adopted the Rhine 2020 - Program on the Sustainable Development of the Rhine (Conference of Rhine Ministers, 2001), which had significant success 
received 10 Sep 2014 accepted 17 Oct 2014

in returning salmon to the river and reducing the flood risk through restoration of natural inundation areas and flood plains. This new kind of basin agreements that introduced cooperation duties with respect to ecosystem protection and restoration happened around the same time as political commitments for cooperation on the global environment started to be formalized in multilateral conventions, such as the CBD and UNFCCC in the early 1990s and onwards.

\section{Codification as a general principle}

Based on the large number of water treaties - almost 450 agreements signed between 1820 and 2007 (UN Water, 2013c) - international expert commissions drafted several instruments codifying the rules of international water law that were considered as universally accepted. Interestingly, the appreciation of cooperation as a recognized duty in the management of resources that link State territories and establish hydrologic interdependence between all countries sharing the waters occurred relatively late in these various codification efforts. The Institute of International Law (IIL) was pioneering the codification efforts with its 1911 Declaration on International Regulation regarding Uses of International Watercourses for Purposes other than Navigation (Wehberg, 1957). In the tradition of the then still prevalent law of coexistence the Regulation focused more on obligations of abstention from interference than on cooperation. Reflecting the evolution towards an international law of cooperation, the 1961 IIL Articles on Utilization of Non-Maritime International Waters (except navigation) included specific cooperation obligations on notification, consultation and negotiation among States planning water uses that may seriously affect the possibility of utilization of the same waters by other countries (IIL, 1961). In 1966, the International Law Association (ILA) contributed to the codification efforts with its landmark Helsinki Rules (ILA, 1967). It is a seldom noted fact that the Helsinki Rules, while firmly establishing the principle of equitable and reasonable utilization 
received 10 Sep 2014 accepted 17 Oct 2014

as one of the general principles of international water law, are fairly guarded on cooperation obligations; only specific obligations limited to the issue areas of pollution, navigation for humanitarian purposes, dispute prevention and timber floating are included. The explicit recognition or confirmation of a general principle of cooperation is absent.

The confirmation of general acceptance of a general duty to cooperate on transboundary water resources management is attributed to codifications of universal rules on pollution prevention. Both the IIL and ILA included a general obligation to cooperate in their respective documents on this topic. The 1979 Athens Resolution of the IIL additionally spells out specific measures for the implementation of this general obligation, including notification, consultation, regular data exchange, coordination of research and monitoring, and technical and financial assistance to developing countries (IIL, 1979). And striking a similar vein, in its commentary to its 1982 Montreal Rules on Water Pollution in an International Drainage Basin, the ILA reasoned that cooperation could now be considered a fundamental principle of international water law (ILA, 1982). Yet, the recognition and legal nature of the general duty to cooperate was again a subject of debate during the long drafting process of the 1994 Draft Articles on the law of nonnavigational uses of international watercourses that later became the basis for the 1997 UN Convention on the Law of the Non-navigational uses of International Watercourses (UNWC). While some members of the International Law Commission (ILC), which undertook the drafting, doubted that the cooperation presented anything more than a principle of international law from which obligations could be derived but was not a duty in and of itself, others argued that it did indeed represent a legal duty, in particular with respect to the management of shared water resources (ILC, 1987). In recognition of this second argument, the general duty to cooperate has been integrated into in Part II of the UNWC on General Principles, which also includes other 
received 10 Sep 2014 accepted 17 Oct 2014

general principles of international water law that are in effect obligations, such as the due diligence obligation not to cause significant harm (Article 7) and the obligation on regular exchange of data and information (Article 9).

The codification of the duty to cooperate among the general principles of international water law acknowledges the fundamental importance of the rule within this body of norms. Cooperation is not only essential for transboundary water resources management, it is also indispensable for bringing other principles and rules of international water law to fruition. For instance, it is not possible to effectively implement the principle of equitable and reasonable utilization without cooperation. Information exchange is required among States about their respective uses, use interests and dependency on the shared water resources, to assess equitable and reasonable use at the basin level.

The UNWC interweaves cooperation duties with substantive provisions and its articles on the principle of equitable and reasonable utilization are an illustrative example. The second paragraph of Article 5, codifying this principle, spells out the right and obligation to participate in the use, development and protection of an international watercourse in an equitable and reasonable manner. And Article 6, which provides a non-exhaustive list of criteria to consider in assessing equity and reasonableness of uses, requires watercourse States to enter into consultations whenever the application of the principle of equitable and reasonable use so requires. Specific obligations to cooperate through consultation, negotiation or exchange of information are also included in the rules on other issue areas for watercourse management and development regulated in the UNWC, including with respect to: eliminating or mitigating significant harm where it occurred (Article 7); the implementation of planned measures (Part III); the protection of ecosystems (Article 20); the prevention of pollution (Article 21); protection 
received 10 Sep 2014 accepted 17 Oct 2014

of the marine environment (Article 23); watercourse management (Article 24); flow regulation (Article 25); and in case of emergencies (Part V). In this sense, the UNWC provides a comprehensive and operational framework for the duty to cooperate (Wouters, 2013b).

Developed by the ILC which brings together the world's most renowned experts of international law from thirty four countries, and adopted by the UN General Assembly with 103 country votes in favor of the document, the UNWC represents today the most authoritative codification of international water law. Its entry into force on 17 August 2014 provides additional legitimacy to the customary principles and rules of international water law, that are codified in the UNWC; including the general duty to cooperate and its expression through various specific cooperation obligations.

\section{Conclusion}

The conclusion of an international treaty is just one step in the iterative and most often incremental process of international cooperation. It is not the first step and it is not an indispensable step of cooperation between States. Collaboration among States also exists in the absence of international treaties. Though this form of cooperation tends to be less stable than treaty based cooperation, because it is dependent on the willingness of parties that are not obliged by any formalized rules to continue the cooperation and thus provides little guarantee of continuation when individual actors change. States use international treaties as tools to provide the process of cooperation with predictability and stability, because treaties bind States and not only the individual governments that conclude them. At the same time, international treaties reflect the political realities at the time of their conclusion. They reflect relative power of the parties at the time of conclusion and provide tools on the basis of which the relatively weaker or 
received 10 Sep 2014 accepted 17 Oct 2014

less endowed countries receive assistance. They reflect political, economic and scientific trends and their impacts. This reflection of trends has led to the emergence of the law of cooperation alongside the law of coexistence over time and it has led to the continuous expansion of the law of cooperation. The universally felt negative impacts of human economic activity have led to increased treaty-based cooperation in general. And in the context of the management of transboundary waters, they have led to the recognition of cooperation as a general principle in international water law and continue the trend of environmentalization of international law through the increased focus on integrated ecosystem management (Boisson de Chazournes, 2013).

States have established rules of cooperation and agree to limit the scope of their sovereignty because cooperation creates new opportunities. The existence of commonly accepted rules of conduct and the establishment joint mechanisms can be mutually beneficial. Experience in transboundary basins shows that cooperation between riparian States more often than not leads to greater benefits for all basin States than non-cooperation. This is one of the reasons why once riparian countries start to engage in cooperation the process tends to be widened in scope over time, both in terms of issue areas covered through cooperation as well as geographically. It is the interdependence between States in the international order more generally, and more particularly with respect to shared water resources, that leads them to make first concessions in good faith so that the concession is reciprocated and the full potential of mutual benefits becomes achievable.

\section{Acknowledgements}

This article is based on a presentation given at the CIWL Symposium "Promoting Transboundary Water Cooperation in Asia”, University of Xiamen Law School, May 2014. The author wishes to thank the 
received 10 Sep 2014 accepted 17 Oct 2014

organizers of the symposium for the opportunity to publish in this volume and the anonymous reviewer for the thoughtful comments.

\section{Disclaimer}

The findings, interpretations and conclusions expressed in the paper are entirely those of the author, and do not represent the views of the World Bank, its Executive Directors, or the countries they represent.

\section{Notes}

1. C. Leb. The UN Watercourses Convention: the éminence grise behind cooperation on transboundary water resources, Water International, 2013 Vol. 38, No. 2, 146-155, http://dx.doi.org/10.1080/02508060.2013.781474

\section{References}

Agreement on the International Commission for the Protection of the Rhine against Pollution. Adopted on April 29, 1963. 994 United Nations Treaty Series (UNTS) 3.

Alvarez, J. E. (2005). International Organizations as Law-makers. Oxford: Oxford University Press.

Biswas, A. (2013). Managing Transboundary Waters of Latin America. New York: Taylor Francis.

Boisson de Chazournes, L. (2005). Eaux internationales et droit international : vers l'idée de gestion commune. In L. Boisson de Chazournes and S. Salman (eds.). Les ressources en eau et le droit international - Water Resources and International Law. Leiden/Boston: Martinus Nijhoff Publishers. 10-30.

Boisson de Chazournes, L. (2013). Fresh Water in International Law. Oxford: Oxford University Press.

Brunnée, J. (1989). “Common Interest” - Echoes from an Empty Shell. Zeitschrift für ausländisches öffentliches Recht und Völkerrecht. 49. 791-808.

Charter of the United Nations (UNC). (1945). Adopted in San Francisco, 26 June 1945. United Nations Treaty Series. 1. XVI. Retrieved from http://www.un.org/en/documents/charter/.

Conference of Rhine Ministers. (2001). Rhine 2020: Program on the sustainable development of the Rhine. Koblenz: ICPR. 
Consulate General of India, Perth (CGI). (2014). Foreign Secretaries Speech on 'Infrastructure Development in the North Eastern Region - Leveraging Opportunities'. Retrieved from http://www.cgiperth.org/scrollingnewsdetail.htm?26/.

Convention on Biological Diversity. Adopted on June 5, 1992. 1970 UNTS 79. Retrieved from http://www.cbd.int/doc/legal/cbd-en.pdf.

Convention on Cooperation for the Protection and Sustainable Use of the Danube River (Danube Protection Convention). Adopted on June 29, 1994. Retrieved from http://www.icpdr.org/main/icpdr/danube-river-protection-convention.

Convention on the Protection of the Rhine. Adopted on April, 12, 1999. Retrieved from http://www.iksr.org/fileadmin/user_upload/Dokumente_en/convention_on_tthe_protection_of_t he_rhine.pdf.

Final Act relating to the Establishment and Operation of the Iron Gates Water Power and Navigation System. Adopted on November 30, 1963. 513 UNTS 12

Friedman, M. (1969). General Course in Public International Law. Recueil de Cours de l'Académie de Droit International (RCADI). 127. 39-224.

Frijters, I. D. and Leentvaar, J. (2003). Rhine Case Study. UNESCO-IHP. Retrieved from http://www.ce.utexas.edu/prof/mckinney/ce397/Topics/Rhine/The_Rhine_case_study.pdf.

Fondo Financiero para al Desarrollo de la Cuenca del Plata (FONPLATA). Retrieved from http://www.fonplata.org/.

Foundation for Non-violent Alternatives (FNVA). (2014). Implementation Plan between the Central Water Commission, Ministry of Water Resources, River Development and Ganga Rejuvenation, the Republic of India and the Bureau of Hydrology and Water Resources, Tibet Autonomous Region, the People's Republic of China upon Provision of Hydrological Information of the Yarlung Zangbu/Brahmaputra River in Flood Season by China to India. Retrieved from http://fnvaworld.org/download/resource-center/2014-July-Implementation-Planbetween-India-and-PRC-for-YTB.pdf.

International Network of Basin Organizations (INBO) News. (2013). Declaration of the High Level International Conference on Water Cooperation. Retrieved from http://www.inbonews.org/IMG/pdf/Dushanbe_Declaration_all_comments_-3.pdf.

Institute of International Law (IIL). (1961). Annuaire de l'Institut de Droit International Session de Salzbourg, September 1961. Basle: Verlag für Recht und Gesellschaft AG.

Institute of International Law (IIL). (1979). Annuaire de l'Institut de droit international, Session d’Athènes 1979. Paris: S. Karger.

International Court of Justice (ICJ). (1969). North Sea Continental Shelf Case (Federal Republic of Germany/Denmark, Federal Republic of Germany/Netherlands), judgment 20 February 1969. ICJ Reports. New York: United Nations. 
received 10 Sep 2014 accepted 17 Oct 2014

International Court of Justice (ICJ). (1986). Military and Paramilitary Activities in and again Nicaragua (Nicaragua v. United States of America), judgment 27 June 1986. ICJ Reports. New York: United Nations.

International Covenant on Civil and Political Rights (ICCPR). Adopted on December 16, 1966. 999 UNTS $171 . \quad$ Retrieved from http://www.ohchr.org/EN/ProfessionalInterest/Pages/CESCR.aspx.

International Covenant on Economic, Social and Cultural Rights (ICESCR). Adopted on December 16, 1966. 993 UNTS 3. Retrieved from http://www.ohchr.org/en/professionalinterest/pages/ccpr.aspx.

International Law Association (ILA). (1967). Report of the Fifty-second Conference, Helsinki, August $14^{\text {th }}$ to August $20^{\text {th }}, 1966$. London: ILA.

International Law Association (ILA). (1982). Report of the Sixtieth Conference, Montreal. London: ILA.

International Law Commission (ILC). (1987). Summary records of the meetings of the thirtyninth session 4 May-17 July 1987. In ILC. Yearbook of the International Law Commission 1987 vol. I. UN Doc. A/CN.4/SER.A/1987.

Leb, C. (2013a). Cooperation in the Law of Transboundary Water Resources. New York: Cambridge University Press.

Leb, C. (2013b). The UN Watercourses Convention: the eminence grise behind cooperation on transboundary water resources. Water International. 38:2. 146-155.

Pochat, V. (2011). International Agreements, Institutions and Projects in La Plata River Basin. International Journal of Water Resources Development. 27:3. 497-510.

Sahovič, M. (1972). Codification of the Law of Friendly Relations between States. Recueil de Cours de l'Académie de Droit International (RCADI). 137. 243-310.

Stockholm International Water Institute (SIWI). (2013). 2013 Overarching Conclusions - World Water Week 2013: Water Cooperation - Building Partnerships. Retrieved from http://www.siwi.org/wp-content/uploads/2013/11/2013-Overarching-Conclusions-web.pdf.

Treaty concerning the Construction and Operation of the Gabčíkovo-Nagymaros System of Locks. Adopted on, September 16, 1977. 1109 UNTS 236

Treaty of the River Plate Basin. Adopted on April 23, 1969. 875 UNTS 11

United Nations Conference on Environment and Development (UNCED). (1992). Rio Declaration on Environment and Development. UN Doc. A/CONF.151/26 (Vol. I).

Convention on the Law of Non-Navigational Uses of International Watercourses. Adopted on May 21, 1997. UN Doc. A/RES/51/299. 
United Nations Framework Convention on Climate Change. Adopted 9 May 1992. 1771 UNTS $165 . \quad$ Retrieved from http://unfccc.int/files/essential_background/background_publications_htmlpdf/application/pdf/co nveng.pdf.

United Nations General Assembly (UNGA). (1948). International Bill of Human Rights. GA Res. 217 (III). $\quad$ Retrieved from http://daccess-ddsny.un.org/doc/RESOLUTION/GEN/NR0/043/88/IMG/NR004388.pdf?OpenElement.

United Nations General Assembly (UNGA). (1963). Question of equitable representation on the Security Council and the Economic and Social Council. GA Res. 1991 (XVIII). Retrieved from http://www.un.org/en/ga/search/view_doc.asp?symbol=A/RES/1991(XVIII)\&Lang=E.

United Nations General Assembly (UNGA). (1970). Declaration on Principles of International Law Concerning Friendly Relations and Cooperation among States. GA Res. 2625 (XXV). UN Doc. A/80821970.

United Nations General Assembly (UNGA). (1974). Declaration on the Establishment of a New International Economic Order. GA Res. 3201 (S-VI). UN Doc. A/RES/S-6/3201.

UN Water. (2013a). World Water Day 2013 International Year of Water Cooperation. Retrieved from http://www.unwater.org/water-cooperation-2013/water-cooperation/water-cooperation/en/.

UN Water. (2013b). Factsheet: Water Scarcity. Retrieved from http://www.unwater.org/fileadmin/user_upload/watercooperation2013/doc/Factsheets/water_scar city.pdf.

UN Water. (2013c). Factsheet: Transboundary Waters. Retrieved from http://www.unwater.org/fileadmin/user_upload/watercooperation2013/doc/Factsheets/transbound ary_waters.pdf.

Verdross, A. and Simma, B. (1984). Universelles Völkerrecht. $3^{\text {rd }}$ ed. Berlin: Duncker \& Humblot.

Wehberg, H. (1957). Tableau Général des Résolutions (1873-1956). Basle: Verlag für Recht und Gesellschaft AG.

Wouters, P. (2013a). International Law - Facilitating Transboundary Water Cooperation. Global Water Partnership (GWP) Background Paper No. 17.

Wouters, P. (2013b). 'Dynamic Cooperation' in international law and the shadow of state sovereignty in the context of transboundary waters (Part 2). Environmental Liability. 4. 131-144.

Wouters, P. (2014). The Yin and Yang of International Water Law: China's Transboundary Water Practice and the Changing Contours of State Sovereignty. Review of European, Comparative \& International Environmental Law. 23 (1). 67-75.

Zartman, I. W. (2008). Concept: Cooperation. PIN Points. 30. 5-7. 